\title{
SPECIFIC CONDUCTANCE REDUCTION IN VALLEY FILL RUNOFF USING THE COST-EFFECTIVE SULFATE REMOVAL PROCESS ${ }^{1}$
}

\author{
Catherine V. Grey², Gregory D. Boardman, Jeffrey Parks, Zachary Kemak, and Kristin Gunther
}

\begin{abstract}
In recent years, the specific conductance (SC) of Appalachian coal mining runoff waters has become a parameter of concern with the EPA due to its negative effect on aquatic life and water quality. In order to comply with the EPA guidance suggesting an effluent SC of $500 \mu \mathrm{S} / \mathrm{cm}$, the Appalachian Research Initiative for Environmental Science (ARIES) Center at Virginia Tech requested that testing be conducted to determine the most effective technologies for reduction of SC. Runoff water was collected from two sites in southwestern Virginia and characterized to determine the source of SC. The primary contributing ions were determined to be $\mathrm{Na}^{+}, \mathrm{Mg}^{2+}, \mathrm{Ca}^{2+}$, and $\mathrm{SO}_{4}{ }^{2-}$. Once characterized, the sample water was treated using a two-step precipitation method called the Cost-Effective Sulfate Removal (CESR) process. Study results indicate that source water with an SC of 1,500-2,500 $\mu \mathrm{S} / \mathrm{cm}$ could be successfully reduced below the proposed EPA limit of $500 \mu \mathrm{S} / \mathrm{cm}$ when the second step of the CESR process lasted 18 hours and the reagent dose was $1.25 \mathrm{x}$ the source water sulfate concentration. The success of this process was due to its ability to remove more than $85 \%$ of the $\mathrm{Ca}, \mathrm{Mg}$, and $\mathrm{SO}_{4}{ }^{2-}$ from the water, which together accounted for more than $90 \%$ of ions in the source water.
\end{abstract}

Additional Key Words: Electrical Conductivity, Appalachia, CESR

${ }^{1}$ Paper submitted to JASMR for publication.

${ }^{2}$ Catherine Grey is a master's degree recipient, Gregory D. Boardman is a Professor Emeritus, Jeffrey Parks is a Research Scientist, Zachary E. Kemak is a master's degree recipient, and Kristin Gunther is a bachelor's degree recipient, Civil and Environmental Engineering Department, Virginia Tech, Blacksburg, VA 24061.

Journal American Society of Mining and Reclamation, 2018 Volume 7, Issue 1 pp 56-76

DOI: http://doi.org/10.21000/JASMR18010056 


\section{Introduction}

Coal mines in central Appalachia that dispose of mining spoils in valley fills have been identified as a contributor to elevated specific conductance (SC) in receiving streams (Pond et al., 2014; Timpano et al., 2010). Runoff waters from these areas, which contain elevated levels of $\mathrm{Ca}^{2+}, \mathrm{Mg}^{2+}, \mathrm{HCO}_{3}{ }^{-}$, and $\mathrm{SO}_{4}{ }^{2-}$, have been shown to significantly impact the benthic organisms in receiving streams. The goal of this study was to reduce the concentration of the primary ions of concern in waters from two surface mining sites in Southwest Virginia, Office Fill (OF) and Barton Hollow (BH), using an engineered precipitation technique.

The CESR process, which targets sulfate as well as Ca and Mg, was developed in the 1990's by European engineers (Reinsel, 2015a). The process has been used in over twenty full-scale treatment plants in Europe but has not yet achieved widespread use in the United States (APEX Engineering, 2016; Lorax, 2003). This innovative process can achieve effluent sulfate levels of less than $100 \mathrm{mg} / \mathrm{L}$, for a much lower cost than conventionally used processes like Reverse Osmosis (RO) and ion exchange (Water Online, 2016). In one application of the CESR process using sample water from Berkeley Pit, an acid mine site in Butte, Montana, water with an initial sulfate concentration of $8,700 \mathrm{mg} / \mathrm{L}$ was reduced to an effluent concentration of $56 \mathrm{mg} / \mathrm{L}$. The average cost of this process was determined to be $\$ 0.79 / \mathrm{m}^{3}$ of treated water when removing $1,500 \mathrm{mg} / \mathrm{L}$ of $\mathrm{SO}_{4}{ }^{2-}$. The estimated upper level cost of treatment was found to be $\$ 1.58 / \mathrm{m}^{3}$ (Lorax, 2003). The process was also used to treat waters at a copper mine with an initial $\mathrm{SO}_{4}{ }^{2-}$ concentration of $3,350 \mathrm{mg} / \mathrm{L}$; the effluent sulfate concentration was $360 \mathrm{mg} / \mathrm{L}$ (Water Online, 2016).

The CESR process is a two-stage precipitation method for waters containing $\mathrm{Na}, \mathrm{Ca}$, and $\mathrm{SO}_{4}{ }^{2-}$. In Stage $\mathrm{I}$, the goal is to precipitate gypsum $\left(\mathrm{CaSO}_{4}\right)$ to its lowest solubility limit of $2,000 \mathrm{mg} / \mathrm{L}$. This is done by increasing the $\mathrm{pH}$ of the water to 10.5 with a slurry of $\mathrm{CaO}$ and water and stirring the mixture for 40 minutes at $100 \mathrm{rpm}$ in a jar stirrer (Reinsel, 2015b).

After the mixture has been stirred for 40 mins, the jar stirrer should then be adjusted to $20 \mathrm{rpm}$ and $2 \mathrm{mg} / \mathrm{L}$ of polymer should be added. This rate of stirring is continued for a minimum of five minutes to promote flocculation. The stirrer is then turned off and the precipitate is allowed to settle. The gypsum is removed for dewatering before continuing with Stage II because any 
remaining gypsum will react with the Stage II reagent and prevent optimal $\mathrm{SO}_{4}{ }^{2-}$ precipitation (Reinsel, 2015b).

After removing the gypsum in Stage I, additional lime is added to the water to raise the $\mathrm{pH}$ to 11.3. The reagent, Luminite MG-4, is then added at a concentration of 1.0-1.5 times the concentration of sulfate in the water. During the process, the $\mathrm{pH}$ will decrease as sulfate precipitates, and it is necessary to ensure the $\mathrm{pH}$ remains near 11.3. If the $\mathrm{pH}$ decreases below 11.0, the reaction will stop; however, if the $\mathrm{pH}$ is above 12 , the reaction may reverse. When the $\mathrm{pH}$ stabilizes, further treatment of the water will not result in additional sulfate removal. At this point, 2 ppm of the polymer flocculent Magnafloc 155 should be added to the reactor and the water should be stirred in for a minimum of five minutes, after which the stirrer should be turned off and the jar should be allowed to settle. The water should be removed and re-carbonated to a neutral $\mathrm{pH}$ before discharge. The precipitate should be dewatered and prepared for disposal. (Reinsel, 2015b). A schematic of the CESR process is shown in Fig. 1.

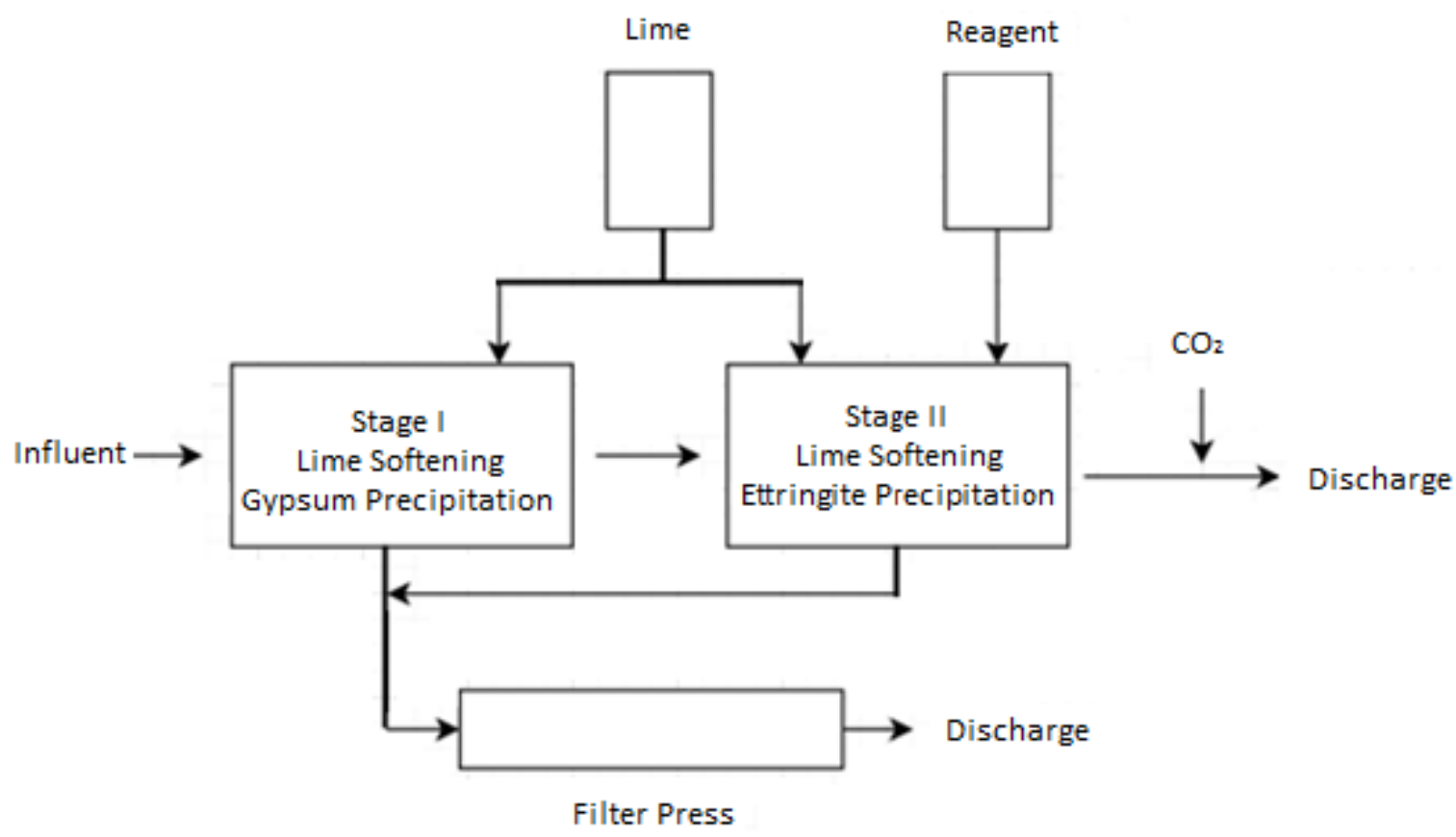

Figure 1. CESR Process Diagram ${ }^{1}$

${ }^{1}$ Due to the complexity of this process, it is suggested that any implementation on site be fully automated. 
The precipitate from the CESR process is ettringite, a unique calcium-alumina-sulfate compound with the formula $3 \mathrm{CaO} \cdot \mathrm{Al}_{2} \mathrm{O}_{3} \cdot 3 \mathrm{CaSO}_{4} \cdot 3 \mathrm{H}_{2} \mathrm{O}(\mathrm{PCA}, 2001)$. Ettringite has a polishing effect on the water and has been shown to bring concentrations for metals such as $\mathrm{Cr}$, As, and $\mathrm{Se}$ down below their detection limits. Up to a third of dissolved $\mathrm{Cl}^{-}$and $\mathrm{NO}_{3}{ }^{-}$in source water may also be removed during precipitation of this mineral. Ettringite can also be disposed of as nonhazardous waste; however, sludge disposal is still a key consideration of the process. Large amounts of ettringite precipitate are produced during Stage II of the process, approximately $45 \mathrm{lbs} /$ per 1,000 gallons of water treated (Water Online, 2016). Sludge tested in the lab showed that precipitate was $80 \%-85 \%$ water; dewatering sludge on site may substantially reduce disposal costs.

An integral component for successful implementation of the CESR process is determining the ideal Stage II reagent dose. Although the reagent (Luminite MG-4) is inexpensive (approximately $\$ 0.40 / \mathrm{lb}$ in 2016), it contains $\mathrm{Al}$, which may be present in effluent if excess reagent is added to the reactor. Aluminum can cause pulmonary and developmental problems in fish and benthic organisms that breathe using gills, the most notable sign of which is an inability of the animal to regulate osmosis (USEPA, 2016; Rosseland, 1990). Furthermore, it is possible that Al could enter the food chain through plants' nutrient uptake from the soil (Rosseland, 1990). Aluminum is least soluble at a neutral $\mathrm{pH}$, between 6.5 and 9.0, has a chronic toxicity value of $748 \mu \mathrm{g} / \mathrm{L}$, and an acute toxicity value of $1,496 \mu \mathrm{g} / \mathrm{L}$ for freshwater organisms (USEPA, 1988). Due to the low toxicity values for aluminum, it is imperative to maintain low aluminum concentrations in CESR effluent. The objectives of the experiments were to determine:

1. The effect of the CESR process on effluent SC and the ionic composition of source water.

2. The quantity of sludge produced by chemical softening and the CESR process.

3. The appropriate dose of the reagent, Luminite MG-4, necessary for optimal sulfate removal in Stage II of the CESR process.

4. An average treatment time for CESR Stage II precipitation.

5. Any challenges or limitations of implementing each process at a site.

\section{Methods}

Analysis of Samples 
The cations measured in this study were $\mathrm{Ca}^{2+}, \mathrm{Mg}^{2+}, \mathrm{Na}^{+}$, and $\mathrm{K}^{+}$. These cations and silicon (Si) were measured using an ICP-MS instrument (X Series ICP-MS, Thermo Electron Corporation). The anions, $\mathrm{SO}_{4}{ }^{2-}, \mathrm{NO}_{3}{ }^{-}$, and $\mathrm{Cl}^{-}$, were measured using an ion chromatograph (Dionex ICS-1600, Thermo Electron Corporation). An Omega CDH-SD1 conductivity meter was used to measure temperature and specific conductance. A pH Controller (DL125 Black Box Series, Milwaukee Instruments) was used to measure and control the $\mathrm{pH}$ of reactors during Stage II of the CESR process. Alkalinity, Total Dissolved Solids (TDS), and Total Suspended Solids (TSS) were measured in accordance with Standard Methods (APHA, 2012; method numbers 2320B, 2540B, and 2540 D, respectively). Turbidity was measured using a Turbidimeter (Digital Direct-Reading Turbidimeter, Orbeco-Hellige).

The chemicals used in these softening experiments were $\mathrm{CaO}$, which becomes hydrated lime in water, and Luminite MG-4.

Capillary Suction Times (CST) were performed according to Standard Methods (APHA, 2012; Method Number $2710 \mathrm{G}$ ) to determine dewatering times for the CESR sludge. Percent moisture was determined using Equation 1, where WW is the wet weight of sludge, and DW is the dry weight of sludge after being dried at $103-105^{\circ} \mathrm{C}$ for one hour.

$$
\% \text { Moisture }=\frac{W W-D W}{W W} * 100 \%
$$

$\underline{\text { Statistical Analysis }}$

The coefficient of variations (COV) was used to determine how variable results of an experiment were with respect to the mean value. The COV was calculated by dividing the sample standard deviation by the average (Fisher, 1950).

Experimental Materials and Conditions

Sample waters were collected at two surface mining sites: Office Fill (OF, Coordinates 37.066, -82.152) and Barton Hollow (BH, Coordinates 37.069, -82.135).

Stage I: $600 \mathrm{~mL}$ of raw water was added to $1,000 \mathrm{~mL}$ gator jars, which served as the reactors for these experiments. The $\mathrm{pH}$ of the water was increased to 10.5 by pumping a solution of $15 \%$ hydrated lime into the water using a pH controller (DL125 Black Box pH Controller, Milwaukee Instruments). The instrument measured and maintained the $\mathrm{pH}$. The solution was stirred at 100 rpm for 40 minutes. After 40 minutes, 2 mg/L of Magnafloc 155 (BASF, Tucson, AZ) was added, 
and the mixture was stirred at $20 \mathrm{rpm}$ for 5 minutes. The reactor was allowed to settle for 10 minutes or more, until the water was clarified. Precipitate formed in this step was dense and settled quickly.

Stage II: $500 \mathrm{~mL}$ of the water was decanted and its $\mathrm{pH}$ was maintained at 11.3 using the $\mathrm{pH}$ controller. The probe of the $\mathrm{pH}$ controller was attached to the side of the gator jar at a height for which the sensor of the probe was entirely immersed. The jar stirrer was set to $100 \mathrm{rpm}$ and the reagent, Luminite MG-4, was added to the reactor after being weighed in its dry powder form on an Entris Sartorius scale (1.0001g precision). The reagent was added to achieve a concentration that was 1.0-1.5 times the influent sulfate concentration. After adding the reagent, the $\mathrm{pH}$ decreased and a precipitate formed, presumably ettringite $\left(3 \mathrm{CaO} \bullet \mathrm{Al}_{2} \mathrm{O}_{3} \cdot 3 \mathrm{CaSO}_{4} \cdot 3 \mathrm{H}_{2} \mathrm{O}\right)(\mathrm{PCA}$, 2011). When the $\mathrm{pH}$ decreased below 11.3, the $\mathrm{pH}$ controller would activate the pump, which pumped the $15 \%$ hydrated lime into the water until the $\mathrm{pH}$ was once again above 11.3. Because it was difficult to assess when $\mathrm{SO}_{4}{ }^{2-}$ precipitation ceased, reaction times of 8, 12, and 18 hours were tested. After the allotted amount of time, the stirrer was decreased to $20 \mathrm{rpm}$ and $2 \mathrm{mg} / \mathrm{L}$ of the polymer flocculent, Magnafloc 155, was added. After flocculent addition, the reactor was stirred at $20 \mathrm{rpm}$ for 10 minutes, and the floc was allowed to settle for 30 minutes. During bench testing, 10 minutes of flocculation was found to produce larger, faster settling sludge than the 5 minutes of flocculation that had been sufficient in Stage I. After settling, the SC and ionic composition of the water were tested, and the dewatering times and water content of the sludge were determined.

Proper maintenance of the $\mathrm{pH}$ control system is one of the most important aspects of sulfate removal in Stage II. To prevent damage to the $\mathrm{pH}$ probe in both stages, it should be removed from the water before the flocculent is added. If not removed, the probe will be coated in a sticky sludge that cannot be easily removed. In addition, the probe needed to be regularly cleaned in an acidic solution to remove scaling caused by the high level of water hardness in the mining waters.

\section{$\underline{\text { Results }}$}

\section{Study Site Characteristics}

At both sites, mining spoils were placed in valleys (valley fills). Water samples collected from $\mathrm{OF}$ and $\mathrm{BH}$ were similar in composition to other sites in central Appalachia (USEPA, 2011; Clark, 2016; Timpano, 2010; Pond et al., 2014). Office Fill had the higher SC of the two sites, with an initial SC value of $2,500 \mu \mathrm{S} / \mathrm{cm}$, as compared to $1,500 \mu \mathrm{S} / \mathrm{cm}$ at $\mathrm{BH}$. The water from both sites 
was clear, with turbidities less than 10 NTU. The TSS concentration was $12 \mathrm{mg} / \mathrm{L}$ at $\mathrm{OF}$ and $16 \mathrm{mg} / \mathrm{L}$ at BH. Water at both sites had a neutral $\mathrm{pH}$ and high TDS. Total Dissolved Solids in $\mathrm{mg} / \mathrm{L}$ for these sites was $0.8-0.9$ of the $\mathrm{SC}$ in $\mu \mathrm{S} / \mathrm{cm}$ (Kemak, 2016). Table 1 provides additional information regarding the source waters.

Table 1. pH, SC, TDS, TSS, alkalinity and turbidity of Office Fill and Barton Hollow source water

\begin{tabular}{|c|c|c|c|c|c|c|}
\hline Site & $\mathrm{pH}$ & $\begin{array}{c}\mathrm{SC} \\
\mu \mathrm{S} / \mathrm{cm}\end{array}$ & $\begin{array}{l}\text { TDS } \\
\mathrm{mg} / \mathrm{L}\end{array}$ & $\begin{array}{l}\mathrm{TSS} \\
\mathrm{mg} / \mathrm{L}\end{array}$ & $\begin{array}{c}\text { Alkalinity } \\
\text { mg/L } \mathrm{CaCO}_{3}\end{array}$ & $\begin{array}{c}\text { Turbidity } \\
\text { NTU }\end{array}$ \\
\hline Office Fill & 7.61 & 2,510 & 2,265 & 12 & 198 & 9.9 \\
\hline $\begin{array}{l}\text { Barton } \\
\text { Hollow }\end{array}$ & 7.44 & 1,532 & 1,200 & 16 & 79 & 8.1 \\
\hline
\end{tabular}

Tables 2 and 3 show the concentration of ions in the sample water and a cation-anion balance for each site's water. TDS at both sites, and therefore SC, was dominated by three key ions: $\mathrm{Ca}^{+2}$, $\mathrm{Mg}^{+2}$, and $\mathrm{SO}_{4}{ }^{2-}$. At $\mathrm{OF}$, the water was very hard, with a Ca concentration of $350 \mathrm{mg} / \mathrm{L}$ and a $\mathrm{Mg}$ concentration of $250 \mathrm{mg} / \mathrm{L}$. Sulfate and bicarbonate were the prominent anions, with the sulfate concentration near $1,500 \mathrm{mg} / \mathrm{L}$ and a bicarbonate concentration of $240 \mathrm{mg} / \mathrm{L}$. Even at the high bicarbonate concentration, sulfate still accounted for approximately $85 \%$ of the anions (in equivalents) at $\mathrm{OF}$.

At $\mathrm{BH}$, concentrations of all ions were significantly lower, as was the SC. Calcium and $\mathrm{Mg}$ were again the dominant cations, at concentrations of $180 \mathrm{mg} / \mathrm{L}$ and $95 \mathrm{mg} / \mathrm{L}$ respectively. Sulfate concentrations at $\mathrm{BH}$ were about $775 \mathrm{mg} / \mathrm{L}$, about half the concentration of $\mathrm{OF}$ water, and bicarbonate concentrations were around $100 \mathrm{mg} / \mathrm{L}$. As at $\mathrm{OF}$, the $\mathrm{SO}_{4}{ }^{2-}$ concentration at $\mathrm{BH}$ accounted for about $85 \%$ of the total anions in the sample water.

The cation-anion balance had a percent difference of less than $10 \%$ for both sites, indicating that the composition of the water was reasonably characterized. Office Fill cations summed to $39.4 \mathrm{meq} / \mathrm{L}$, and anions summed to 36.9 , creating a percent difference of $6.4 \%$. At $\mathrm{BH}$, the total cation concentration was $17.94 \mathrm{meq} / \mathrm{L}$ with an anion concentration of $17.84 \mathrm{meq} / \mathrm{L}$, a percent difference of $0.5 \%$. 
Journal American Society of Mining and Reclamation, 2018 Vol.7, No.1

Table 2. Cation-anion balance for source water from Office Fill.

\begin{tabular}{cccc}
\hline Constituent & $\mathrm{mg} / \mathrm{L}$ & $\mathrm{meq} / \mathrm{L}$ & Sum $[\mathrm{meq} / \mathrm{L}]$ \\
\hline $\mathrm{Ca}^{2+}$ & 346.0 & 17.26 & \\
$\mathrm{Mg}^{2+}$ & 247.1 & 20.34 & 39.43 \\
$\mathrm{~K}^{+}$ & 10.5 & 0.27 & \\
$\mathrm{Na}^{+}$ & 36.0 & 1.57 & 36.90 \\
$\mathrm{HCO}_{3}^{-}$ & 241.6 & 3.96 & \\
$\mathrm{SO}_{4}{ }^{-}$ & $1,531.0$ & 31.86 & \\
$\mathrm{NO}^{-}$ & 3.5 & 0.25 & \\
$\mathrm{Cl}^{-}$ & 29.3 & 0.83 & \\
\hline
\end{tabular}

Table 3. Cation-anion balance for source water from Barton Hollow.

\begin{tabular}{cccc}
\hline Constituent & $\mathrm{mg} / \mathrm{L}$ & $\mathrm{meq} / \mathrm{L}$ & Sum $[\mathrm{meq} / \mathrm{L}]$ \\
\hline $\mathrm{Ca}^{2+}$ & 181.4 & 9.04 & \\
$\mathrm{Mg}^{2+}$ & 93.6 & 7.70 & 17.94 \\
$\mathrm{~K}^{+}$ & 7.7 & 0.20 & \\
$\mathrm{Na}^{+}$ & 22.8 & 0.99 & \\
$\mathrm{HCO}^{-}$ & 96.39 & 1.58 & 17.84 \\
$\mathrm{SO}_{4}{ }^{2-}$ & 775.8 & 16.15 & \\
$\mathrm{NO}_{3}{ }^{-}$as & 4.0 & 0.11 & \\
$\mathrm{Cl}^{-}$ & 4.1 & 0.58 & \\
\hline
\end{tabular}

Silicon, which is often found in the $\mathrm{Si}^{4-}$ form in natural waters, was also measured at these sites. The concentration at $\mathrm{OF}$ was $0.64 \mathrm{meq} / \mathrm{L}$ and at $\mathrm{BH}$ was $0.58 \mathrm{meq} / \mathrm{L}$.

\section{$\underline{\text { CESR Process Effluent }}$}

Two initial tests were performed by dosing the water with Luminite MG-4 at 1.5 times (x) the $\mathrm{SO}_{4}{ }^{2-}$ concentration and allowing the reaction to occur for eight hours in Stage II. Although the SC was reduced under these conditions (Table 4) by an average of 55\% for OF waters and $44 \%$ at 
$\mathrm{BH}$, the ICP analysis (Table 5) revealed that there was far more potential for the removal of $\mathrm{SO}_{4}{ }^{2-}$. Aluminum and $\mathrm{SO}_{4}{ }^{2-}$ concentrations were both high in the test water effluent, with an average concentration of $39 \mathrm{mg} / \mathrm{L} \mathrm{Al}$ and $620 \mathrm{mg} / \mathrm{L} \mathrm{SO}_{4}{ }^{2-}$ in the OF effluent, and $38 \mathrm{mg} / \mathrm{L} \mathrm{Al}$ and $343 \mathrm{mg} / \mathrm{L} \mathrm{SO}_{4}{ }^{2-}$ in the $\mathrm{BH}$ effluent. Water treated with the CESR process has been shown to have effluent sulfate concentrations below $100 \mathrm{mg} / \mathrm{L}$; this information, coupled with the high concentration of reagent remaining, made it clear that the reaction time was not long enough. An additional takeaway from the high effluent $\mathrm{Al}$ concentration was that reagent dosing was too high for the source water's composition.

Table 4. SC of clarified water and sludge produced from CESR process using a reagent concentration of $1.5 \times$ the $\mathrm{SO}_{4}{ }^{2-}$ concentration and an 8-hour reaction time.

\begin{tabular}{ccccccccc}
\hline & \multicolumn{2}{c}{ OF Stage 1 } & \multicolumn{2}{c}{ OF Stage 2 } & \multicolumn{2}{c}{ BH Stage 1 } & \multicolumn{2}{c}{ BH Stage 2 } \\
& Avg & COV & Avg & COV & Avg & COV & Avg & COV \\
\hline SC, $\mu \mathrm{S} / \mathrm{cm}^{*}$ & 2,065 & $30 \%$ & 1,137 & $54 \%$ & 1,409 & $17 \%$ & 862 & $28 \%$ \\
& & & & & & & & \\
$\begin{array}{c}\text { Sludge, \% of } \\
\text { water volume }\end{array}$ & $0.33 \%$ & $71 \%$ & $8.3 \%$ & $97 \%$ & $0.25 \%$ & $47 \%$ & $10.9 \%$ & $110 \%$ \\
\hline
\end{tabular}

*Two replicates per site were performed for this trial

Table 5. Ionic composition of CESR process effluent water: reagent concentration of $1.5 \mathrm{x}$ the $\mathrm{SO}_{4}{ }^{2-}$ concentration and an 8-hour reaction time

\begin{tabular}{cccccccc}
\hline & \multicolumn{7}{c}{ Concentration $[\mathrm{mg} / \mathrm{L}]$} \\
Replicate & $\mathrm{Al}$ & $\mathrm{S}$ & $\mathrm{Ca}$ & $\mathrm{Mg}$ & $\mathrm{Na}$ & $\mathrm{K}$ & $\mathrm{Cl}$ \\
\hline OF Source* $^{*}$ & 0 & $1,500.0$ & 346.0 & 247.1 & 36.0 & 10.5 & 0.0 \\
OF Rep 1 & 21 & 972 & 418 & 6 & 24 & 8 & 17 \\
OF Rep 2 & 57 & 269 & 158 & 0 & 21 & 8 & 15 \\
BH Source* & 0.0 & 775.8 & 181.4 & 93.6 & 22.8 & 7.7 & 0.0 \\
BH Rep 1 & 36 & 194 & 117 & 3 & 18 & 7 & 3 \\
BH Rep 2 & 41 & 492 & 250 & 0 & 18 & 9 & 4 \\
\hline
\end{tabular}

*Source water values included for reference

A reagent dose of 1.0x the sulfate concentration and a 12-hour reaction time were chosen for the second set of trials to allow a longer window for precipitation to occur. SC reduction under 
these conditions was similar, but slightly more successful than the reduction achieved in the first set of trials, with a $58 \%$ reduction of $\mathrm{SC}$ at $\mathrm{OF}$ and $61 \%$ reduction at $\mathrm{BH}$ (Table 6). Comparison with the ICP results (Table 7) showed that sulfate concentrations at both sites $(\mathrm{OF}=715 \mathrm{mg} / \mathrm{L}$; $\mathrm{BH}=341 \mathrm{mg} / \mathrm{L}$ ) were still far greater than the potential limit of $100 \mathrm{mg} / \mathrm{L}$, though in this trial Al concentrations were low, around $2 \mathrm{mg} / \mathrm{L}$ at both sites. It appeared that a 12-hour reaction time was sufficient for the reagent dose in the second trial, so the next set of trials were conducted using the same reaction time.

Table 6. SC of clarified water and sludge produced from CESR process using a reagent concentration of $1.0 \times$ the $\mathrm{SO}_{4}{ }^{2-}$ concentration and a 12 -hour reaction time.

\begin{tabular}{ccccccccc}
\hline & OF Stage 1 & OF Stage 2 & BH Stage 1 & BH Stage 2 \\
& Avg & COV & Avg & COV & Avg & COV & Avg & COV \\
\hline SC, $\mu \mathrm{S} / \mathrm{cm}^{*}$ & 2,190 & $2 \%$ & 1,569 & $2 \%$ & 1,431 & $16 \%$ & 893 & $25 \%$ \\
$\begin{array}{c}\text { Sludge, } \% \text { of } \\
\text { water volume }\end{array}$ & $\begin{array}{c}0.80 \\
\%\end{array}$ & $112 \%$ & $10.4 \%$ & $103 \%$ & $0.63 \%$ & $104 \%$ & $15.6 \%$ & $121 \%$ \\
\hline
\end{tabular}

*Two replicates per site were performed for this trial

Table 7. Ionic composition of CESR process effluent water: reagent concentration of $1.0 \times$ the $\mathrm{SO}_{4}{ }^{2-}$ concentration and a 12 -hour reaction time

\begin{tabular}{cccccccc}
\hline & & \multicolumn{7}{c}{ Concentration $[\mathrm{mg} / \mathrm{L}]$} \\
Replicate & $\mathrm{Al}$ & $\mathrm{S}$ & $\mathrm{Ca}$ & $\mathrm{Mg}$ & $\mathrm{Na}$ & $\mathrm{K}$ & $\mathrm{Cl}$ \\
\hline OF Source* $^{*}$ & 0 & $1,500.0$ & 346.0 & 247.1 & 36.0 & 10.5 & 0.0 \\
OF Rep 1 & 3 & 990 & 393 & 16 & 22 & 8 & 17 \\
OF Rep 2 & 0 & 441 & 232 & 0 & 19 & 8 & 46 \\
BH Source* & 0.0 & 775.8 & 181.4 & 93.6 & 22.8 & 7.7 & 0.0 \\
BH Rep 1 & 3 & 541 & 172 & 40 & 17 & 7 & 3 \\
BH Rep 2 & 0 & 441 & 232 & 0 & 19 & 8 & 46 \\
\hline
\end{tabular}

*Source water values included for reference

The third set of trials occurred with a reagent dose that was $1.25 \times$ the $\mathrm{SO}_{4}{ }^{2-}$ concentration and using a reaction time of 12 hours. These conditions resulted in an SC reduction of about $50 \%$ for 
both $\mathrm{BH}$ and $\mathrm{OF}$ (Table 8). ICP results from Table 9 showed that Al concentrations in Stage II effluent were approximately $16 \mathrm{mg} / \mathrm{L}$ for both sites, while $\mathrm{SO}_{4}{ }^{2-}$ concentrations were well above $100 \mathrm{mg} / \mathrm{L}(585 \mathrm{mg} / \mathrm{L}$ at $\mathrm{OF}, 300 \mathrm{mg} / \mathrm{L}$ at $\mathrm{BH})$. The presence of both high $\mathrm{Al}$ and $\mathrm{SO}_{4}{ }^{2-}$ concentrations in the water indicated that the dosing could feasibly be correct, but the reaction time was too short.

Table 8. SC of clarified water and sludge produced from CESR process using a reagent concentration of $1.25 \mathrm{x}$ the $\mathrm{SO}_{4}{ }^{2-}$ concentration and a 12 -hour reaction time

\begin{tabular}{ccccccccc}
\hline & \multicolumn{2}{c}{ OF Stage 1 } & OF Stage 2 & BH Stage 1 & \multicolumn{2}{c}{ BH Stage 2 } \\
& Avg & COV & Avg & COV & Avg & COV & Avg & COV \\
\hline $\begin{array}{c}\text { SC, } \mu \mathrm{S} / \mathrm{cm}^{*} \\
\begin{array}{c}\text { Sludge, } \% \text { of } \\
\text { water volume }\end{array}\end{array}$ & 2,307 & $23 \%$ & 1,224 & $43 \%$ & 1,454 & $21 \%$ & 783 & $40 \%$ \\
\hline
\end{tabular}

*Three replicates per site were performed for this trial

Table 9. Ionic composition of CESR process effluent water: reagent concentration of $1.25 \mathrm{x}$ the $\mathrm{SO}_{4}{ }^{2-}$ concentration and a 12 -hour reaction time.

\begin{tabular}{cccccccc}
\hline & \multicolumn{7}{c}{ Concentration $[\mathrm{mg} / \mathrm{L}]$} \\
Sample & $\mathrm{Al}$ & $\mathrm{S}$ & $\mathrm{Ca}$ & $\mathrm{Mg}$ & $\mathrm{Na}$ & $\mathrm{K}$ & $\mathrm{Cl}$ \\
\hline OF Source* & 0 & $1,500.0$ & 346.0 & 247.1 & 36.0 & 10.5 & 0.0 \\
OF Rep 1 & 43 & 201 & 109 & 0 & 27 & 16 & 26 \\
OF Rep 2 & 1 & 1,046 & 465 & 1 & 39 & 16 & 29 \\
OF Rep 3 & 4 & 508 & 212 & 0 & 27 & 11 & 33 \\
BH Source* & 0.0 & 775.8 & 181.4 & 93.6 & 22.8 & 7.7 & 0.0 \\
BH Rep 1 & 0 & 640 & 203 & 37 & 19 & 7 & 3 \\
BH Rep 2 & 26 & 230 & 106 & 0 & 23 & 10 & 8 \\
BH Rep 3 & 22 & 31 & 45 & 0 & 19 & 10 & 7 \\
\hline
\end{tabular}

*Source water values included for reference 
In the final set of trials, reagent was added at a concentration of $1.25 \times$ the $\mathrm{SO}_{4}{ }^{2-}$ concentration with a Stage II reaction time of eighteen hours. Under these conditions, the Stage II effluent water had a final SC near or below the proposed EPA limit of $500 \mu \mathrm{S} / \mathrm{cm}$.

The average effluent SC in OF Stage II was $442 \mu \mathrm{S} / \mathrm{cm}$, an $82 \%$ reduction from the initial SC value of $2,510 \mu \mathrm{S} / \mathrm{cm}$. The effluent $\mathrm{SC}$ for $\mathrm{BH}$ was similar at $456 \mu \mathrm{S} / \mathrm{cm}$, a $70 \%$ reduction from the initial value of $1,534 \mu \mathrm{S} / \mathrm{cm}$ (Table 10). The Stage II effluent sulfate concentration at both sites was near $100 \mathrm{mg} / \mathrm{L}$, with an average concentration of $119 \mathrm{mg} / \mathrm{L}$ at $\mathrm{OF}$ and $132 \mathrm{mg} / \mathrm{L}$ at $\mathrm{BH}$ (Table 11). The $\mathrm{Ca}$ in the water was also reduced substantially, with an $81 \%$ reduction at $\mathrm{OF}$ and a $59 \%$ reduction at $\mathrm{BH}$. Magnesium at both sites was reduced below detection limits.

The effluent water from all four trials had a $\mathrm{pH}$ above 11.0 when the CESR process was complete. It was lab verified that re-carbonation could return the $\mathrm{pH}$ to a neutral value. $\mathrm{Re}-$ carbonation did not noticeably change the SC of any waters tested.

Table 10. SC of clarified water and sludge produced from CESR process using a reagent concentration of $1.25 \times$ the $\mathrm{SO}_{4}{ }^{2-}$ concentration and an 18 -hour reaction time

\begin{tabular}{ccccccccc}
\hline & \multicolumn{2}{c}{ OF Stage 1 } & \multicolumn{2}{c}{ OF Stage 2 } & \multicolumn{2}{c}{ BH Stage 1 } & \multicolumn{2}{c}{ BH Stage 2 } \\
& Avg & COV & Avg & COV & Avg & COV & Avg & COV \\
\hline SC, $\mu \mathrm{S} / \mathrm{cm}^{*}$ & 2,210 & $4 \%$ & 442 & $19 \%$ & 1,450 & $2 \%$ & 456 & $8 \%$ \\
$\begin{array}{c}\text { Sludge, } \% \text { of } \\
\text { water volume }\end{array}$ & $\begin{array}{c}0.83 \\
\%\end{array}$ & $0 \%$ & $21.8 \%$ & $9 \%$ & $0.28 \%$ & $69 \%$ & $29.7 \%$ & $34 \%$ \\
\hline
\end{tabular}

*Three replicates per site were performed for this trial

Table 11. Ionic composition of CESR process effluent water: reagent concentration of $1.25 \mathrm{x}$ the $\mathrm{SO}_{4}{ }^{2-}$ concentration and a 18 -hour reaction time.

\begin{tabular}{cccccccc}
\hline & \multicolumn{7}{c}{ Concentration $[\mathrm{mg} / \mathrm{L}]$} \\
Sample & $\mathrm{Al}$ & $\mathrm{S}$ & $\mathrm{Ca}$ & $\mathrm{Mg}$ & $\mathrm{Na}$ & $\mathrm{K}$ & $\mathrm{Cl}$ \\
\hline OF Source* & 0 & $1,500.0$ & 346.0 & 247.1 & 36.0 & 10.5 & 0.0 \\
OF Rep 1 & 10 & 92 & 38 & 0 & 25 & 9 & 26 \\
OF Rep 2 & 14 & 120 & 53 & 0 & 22 & 8 & 22 \\
OF Rep 3 & 18.5 & 144.2 & 101.8 & 0.3 & 15.1 & 6.4 & 2.5 \\
BH Source* & 0.0 & 775.8 & 181.4 & 93.6 & 22.8 & 7.7 & 0.0
\end{tabular}


Journal American Society of Mining and Reclamation, 2018 Vol.7, No.1

$\begin{array}{cccccccc}\text { BH Rep 1 } & 17 & 177 & 81 & 0 & 18 & 9 & 5 \\ \text { BH Rep 2 } & 36 & 90 & 82 & 2 & 17 & 7 & 11 \\ \text { BH Rep 3 } & 13.6 & 128.9 & 61.0 & 0.1 & 22.9 & 11.2 & 3.2\end{array}$

* Source water values included for reference Sludge Characterization

A known limitation of the CESR process is that a high volume of sludge is produced, especially during Stage II. A small amount of dense precipitate is produced in Stage I; sludge volume produced from Stage I averaged $0.2 \%-1.0 \%$ of the volume of water treated. Sludge production in Stage II is much higher, but the variety and quantity of sludge produced depends on a number of factors, including reagent dosing. The sludge volume produced for the Trial 4 reactor conditions averaged $30 \%$ of the process volume before dewatering. Figures 2 and 3 show how the sludge produced from treatment of the $\mathrm{BH}$ and $\mathrm{OF}$ waters settled.

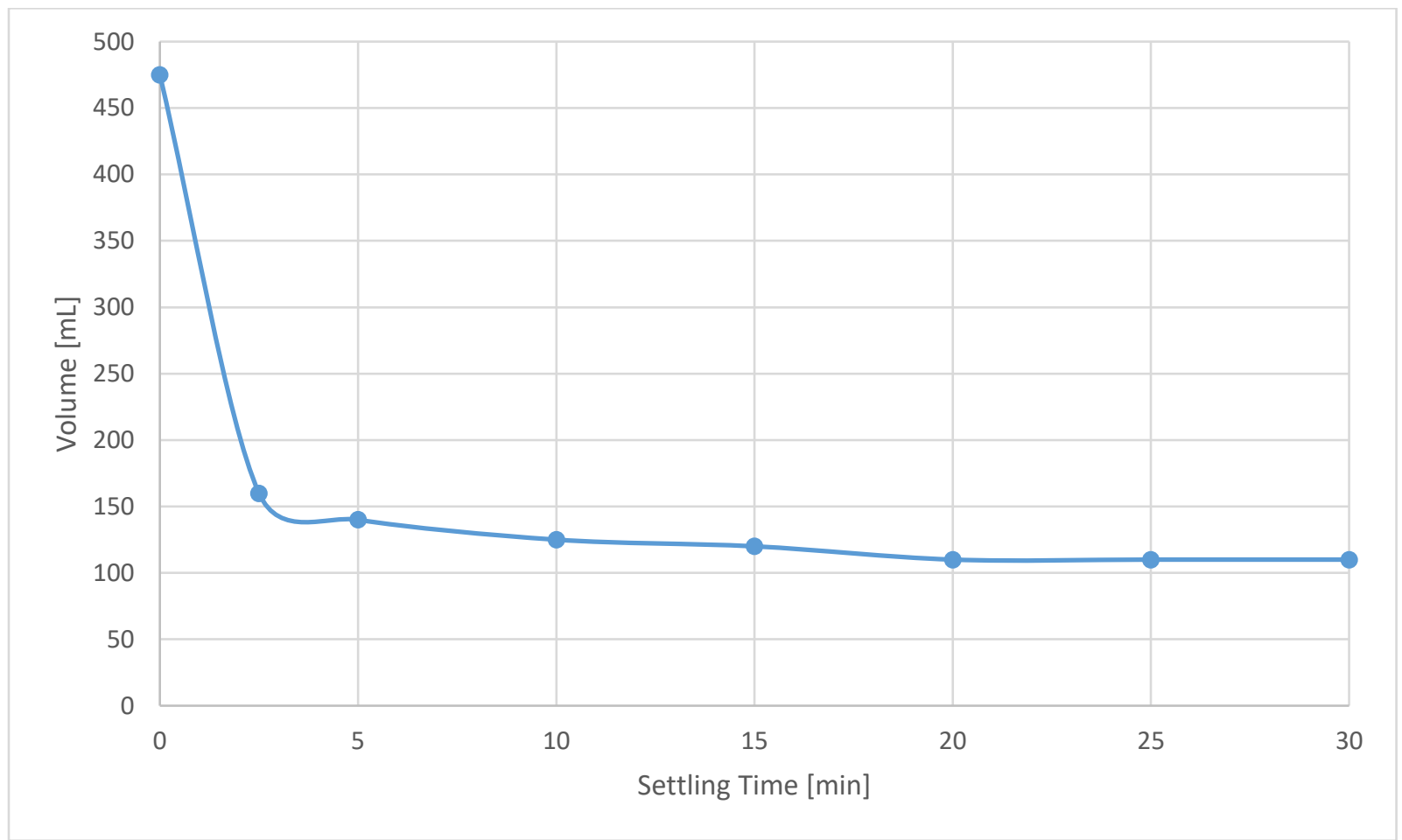

Figure 2. Office Fill sludge settling time. 
Journal American Society of Mining and Reclamation, 2018 Vol.7, No.1

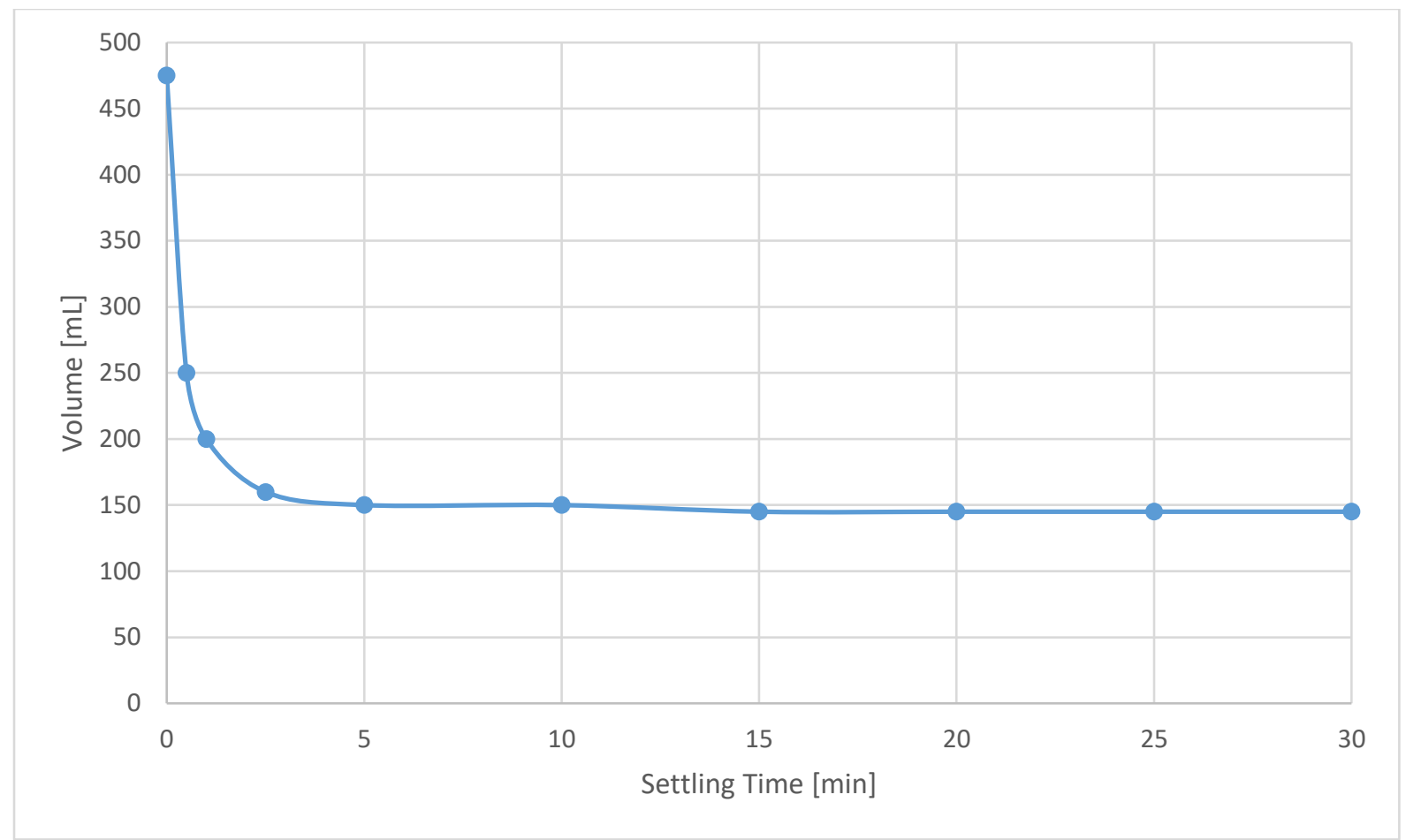

Figure 3. Barton Hollow sludge settling time.

The Capillary Suction Time (CST) of sludge from the Stage 4 trials are shown in Tables 12 and 13. The average CST for OF sludge was 34 seconds, while the average for BH was 20.6 seconds. A CST of 20 seconds is often the goal for wastewater sludge (Vesilind, 1988), though times of 50 seconds or higher have been used as acceptable dewatering times for heavy wastewater sludge (Sawalha and Scholz, 2007). The CST of the CESR sludge is well within this range and can be dewatered without further modification. 
Table 12. Office Fill Sludge Capillary Suction Time.

\begin{tabular}{cccc}
\hline \multicolumn{4}{c}{ Time, Seconds } \\
OF A & OF B & OF C \\
\hline 1 & 26.6 & 40.6 & 41.3 \\
2 & 31.1 & 31.7 & 28.2 \\
3 & 21.2 & 33.9 & 38.8 \\
4 & 36.8 & 38.7 & 34.6 \\
5 & 38.7 & 39.1 & 28.3 \\
Avg & 30.9 & 36.8 & 34.2 \\
COV & $23.4 \%$ & $10.3 \%$ & $17.4 \%$ \\
\hline
\end{tabular}

Table 13. Barton Hollow Capillary Suction Time.

\begin{tabular}{cccc}
\hline & Time, Seconds & \\
Replicate & BH A & BH B & BH C \\
\hline 1 & 29.1 & 14.4 & 29.4 \\
2 & 16.5 & 20.4 & 19.1 \\
3 & 24.4 & 12.9 & 21.5 \\
4 & 27.0 & 16.1 & 27.8 \\
5 & 16.8 & 12.4 & 21.0 \\
Avg & 22.8 & 15.2 & 23.8 \\
COV & $25.6 \%$ & $21.2 \%$ & $19.1 \%$ \\
\hline
\end{tabular}

Testing was also done to determine the percent moisture of sludge from both sites. The percent moisture of OF sludge was $80.7 \%$, while the percent moisture of BH sludge was $85.7 \%$. The COV for both percent moisture values was below $5 \%$. 


\section{$\underline{\text { Discussion }}$}

The three most important factors for success using the CESR process are reagent dose, reaction time, and consistent maintenance of $\mathrm{pH}$ during Stage II. These factors are far easier to control in the lab than on-site where runoff water is inconsistent in composition. Success in dosing and reaction time can be measured by comparing the $\mathrm{Al}$ and $\mathrm{SO}_{4}{ }^{2-}$ concentrations of water, post treatment. If $\mathrm{Al}$ is low and $\mathrm{SO}_{4}{ }^{2-}$ is high, too little reagent was added to the water. If $\mathrm{SO}_{4}{ }^{2-}$ is low and $\mathrm{Al}$ is high, the opposite is true. If $\mathrm{Al}$ and $\mathrm{SO}_{4}{ }^{2-}$ concentrations are both high, not enough time was provided for the precipitate to form. Finally, if both $\mathrm{Al}$ and $\mathrm{SO}_{4}{ }^{2-}$ are high and $\mathrm{Ca}$ concentrations are higher than expected or higher than the initial $\mathrm{Ca}$ concentration, this is an indication that $\mathrm{pH}$ was not controlled in the correct range or the controller has overdosed the water with lime. In this case, the $\mathrm{pH}$ probe should be cleaned in an acidic solution to remove scaling and recalibrated. For the waters used in this study, the best reaction time and dose of reagent were, respectively, 18 hours and $1.25 \times$ the $\mathrm{SO}_{4}{ }^{2-}$ concentration. This dose and time may change based on water composition, but the reagent dose will always be in the range of $1.0 \mathrm{x}-1.5 \mathrm{x}$ the $\mathrm{SO}_{4}{ }^{2-}$ concentration.

The first three trials of the CESR experiments (1.5 x reagent, 8-hour reaction; $1.0 \mathrm{x}$ reagent, 12-hour reaction; and $1.25 \mathrm{x}$ reagent, 12 -hour reaction) superficially yielded very similar results when looking at SC reduction alone. All three trials resulted in SC reductions of 45\%-60\% for waters at both sites, though in none of the trials was the discharge SC of $500 \mu \mathrm{S} / \mathrm{cm}$ met. The key differences between these trials was revealed in the ICP data. In the first trial, effluent Al concentrations were around $40 \mathrm{mg} / \mathrm{L}$ for both waters, $\mathrm{SO}_{4}{ }^{2-}$ reductions were near $60 \%$, and $\mathrm{Ca}$ removals were low (<20\% for both $\mathrm{BH}$ and $\mathrm{OF}$ ). Magnesium removal was near $99 \%$ for both waters in this trial due to the $\mathrm{Mg}$ precipitation that occurs at a $\mathrm{pH}$ of 11 . In the second trial, effluent $\mathrm{Al}$ was a low $(2 \mathrm{mg} / \mathrm{L})$, but removal percentages for $\mathrm{SO}_{4}{ }^{2-}$ were only $52 \%$ at $\mathrm{OF}$ and $56 \%$ at $\mathrm{BH}$. Calcium removal was only $10 \%$ for $\mathrm{OF}$ and $36 \%$ for $\mathrm{BH}$; $\mathrm{Mg}$ removal was similar to that of the first trial.

In the third and fourth trials, a reagent dose of $1.25 \times$ the $\mathrm{SO}_{4}{ }^{2-}$ concentration was used. The third trial was performed using a Stage II reaction time of 12 hours, while the fourth trial had an 18-hour reaction time. In trial 3, the concentration of $\mathrm{Al}$ in the effluent of both site waters was $16 \mathrm{mg} / \mathrm{L}$. Sulfate concentrations for trial 3 were reduced by about $60 \%$ at both sites, and Ca had 
been reduced by $25 \%$ at $\mathrm{OF}$ and $35 \%$ at $\mathrm{BH}$. The presence of notable amounts of both $\mathrm{SO}_{4}{ }^{2-}$ and $\mathrm{Al}$ indicated the need for a longer reaction time, which was tested in trial 4. The effluent in trial 4 had an average of $18 \mathrm{mg} / \mathrm{L}$ of $\mathrm{Al}$ and $\mathrm{a} \mathrm{SO}_{4}{ }^{2-}$ concentration near the expected removal limit for CESR (119 mg/L at OF, $132 \mathrm{mg} / \mathrm{L}$ at BH). The $92 \%$ sulfate removal at $\mathrm{OF}$ and $83 \% \mathrm{SO}_{4}{ }^{2-}$ removal at $\mathrm{BH}$ were complemented by $81 \% \mathrm{Ca}$ removal at $\mathrm{OF}$ and $59 \% \mathrm{Ca}$ removal at $\mathrm{BH}$. Magnesium concentrations in both instances were below the detection limit. The presence of additional $\mathrm{Al}$ in the effluent indicated that a lower reagent dose than the one used in the fourth trial, perhaps a dose of 1.20 times the $\mathrm{SO}_{4}{ }^{2-}$ concentration, might further improve the effluent water quality, lower the final $\mathrm{SC}$, and reduce effluent $\mathrm{Al}$.

It is possible to use the CESR process to achieve reduction of SC when, on a field scale, the primary contributors to $\mathrm{SC}$ are $\mathrm{SO}_{4}{ }^{2-}, \mathrm{Ca}$, and $\mathrm{Mg}$. The key components in ensuring the process is successful are correctly dosing the reagent in Stage II and making sure that the $\mathrm{pH}$ can be correctly measured and controlled at all times. Properly maintaining the $\mathrm{pH}$ probe is a challenge in the CESR reactor, especially in Stage II, because the probe is submerged in water with high concentrations of $\mathrm{Ca}$ and $\mathrm{Mg}$ that often form a scale on exposed surfaces. In order to prevent clogging and eventual destruction of the $\mathrm{pH}$ probe, the sensor should be rinsed well and submerged in an acidic solution after use. The probe should also be removed from the reactors in both Stage I and II before the flocculent is added to prevent a gummy film from forming on the probe.

To generate consistent results during Stage II, it is also imperative to ensure that lime dosing is consistent throughout the operation. If too much lime is in solution, scaling will occur in any tubes or pipes. This is especially important to consider in instances where the pumping system has not been used in some time. During testing, scaling was seen to occur within $\mathrm{pH}$ controller tubing in as little as four days. In this situation, water may build up behind the precipitate until it is forced out, causing an overdose of lime and potentially bringing the Stage II reactor $\mathrm{pH}$ above 12. At this $\mathrm{pH}, \mathrm{SO}_{4}{ }^{2-}$ will no longer precipitate, the CESR process will reverse or stop, and the effluent SC may be higher than the initial SC due to excessive Ca concentrations.

Sludge production is an important factor to consider when designing a precipitation reactor. Stage I sludge production was less than $1 \%$ of treated water volume for both $\mathrm{BH}$ and OF in all trials. Stage II sludge produced under the first three trials was 10\%-20\% of treated water volume. The sludge in the fourth trial was about $20 \%$ of treated water volume at OF and $30 \%$ of the treated 
water volume at $\mathrm{BH}$. Although the original guidelines used for testing stated that five minutes of flocculation would be sufficient, it was determined in the lab that floc was larger and settled more quickly with ten minutes of gentle stirring. After addition of the flocculent and stirring for 10 minutes at $20 \mathrm{rpm}$, sludge from waters at both sites settled to its final volume in approximately 30 minutes. The moisture content of the sludge was similar to typical dewatered wastewater treatment plant sludge ( $80 \%-85 \%$ moisture). It should also be noted that the sludge is not categorized as hazardous. Capillary Suction Time (CST) values for the sludge, as determined using Standard Methods, were 34 seconds for OF and 20.6 seconds for BH. A commonly used CST value for wastewater sludge is 20 seconds (Vesilind, 1988), with CST values above 50 seconds also being acceptable for heavier sludge (Sawalha and Scholz, 2007). When compared to these values, the CESR sludge is reasonably near an acceptable dewatering time for most wastewater residuals even before any further polymer addition or modification.

The goal in coagulation-flocculation operations is to produce large, fluffy floc that settles well. In the CESR process, when lime dosing is inconsistent, flocs may be very large and settle poorly, taking up 50\%-80\% of the reactor volume even after an extensive settling time. An alternative parameter found in the lab is that extremely small diameter floc that accounts for less than $5 \%$ of treated water volume and settles quickly is an indicator that the process has failed. In either of these situations, the CESR process effluent will likely have a high SC and should not be discharged to the environment. Both situations can be avoided with proper care and maintenance of the $\mathrm{pH}$ controller.

There are several challenges for implementing the CESR process at a remote site near a mine that should be noted. The first is that collection of runoff waters and prediction of runoff volume is a challenge around many mining sites. Some streams used in this study were present throughout the year, but others would appear only during and after precipitation events. Those hoping to implement the CESR process on site would need to develop collection systems or know where runoff water collects after storm events. The inconsistency in presence and composition of valley fill runoff waters also means that many sites would be unable to use continuously stirred tank reactors (CSTR's) as a treatment option for two reasons: 1) Inconsistent flow rates would make continuous treatment difficult, and 2) Changes in major ion concentrations, especially $\mathrm{SO}_{4}{ }^{2-\mathrm{k}}$, would create difficulties for proper chemical dosing, most notably the dosing of the Al reagent in Stage II. For the sites in this study, it might be possible to use batch reactors. Using this technique, 
it is possible to know the initial concentrations of important parameters, such as $\mathrm{SO}_{4}{ }^{2-}$, and to prevent overdosing of Luminite MG 4 in Stage II operations.

Although field scale studies are needed, when reagent doses and reactor times are within a certain range, it seems possible this process could reduce SC in mining runoff waters to below the proposed EPA limit of $500 \mu \mathrm{S} / \mathrm{cm}$. The best reagent dose and reaction time for mining waters in this study were, respectively, 1.25 times the $\mathrm{SO}_{4}{ }^{2-}$ concentration and 18 hours. However, the water at different sites should be individually tested to confirm the optimal reagent dose and reaction time. Under the right conditions, the CESR process reduces the concentrations of $\mathrm{SO}_{4}{ }^{2-}, \mathrm{Ca}$, and $\mathrm{Mg}$, the three dominant ions in the source water, by $80 \%-90 \%, 59 \%-81 \%$, and more than $99 \%$, respectively. These three ions combined contributed to approximately $90 \%$ of the chemical equivalents present at both sites, so targeting these ions for removal in waters similar to those at $\mathrm{OF}$ and $\mathrm{BH}$ will yield fruitful results in $\mathrm{SC}$ reduction.

When implementing the CESR process, care should be taken in determining the water's initial $\mathrm{SO}_{4}{ }^{2-}$ concentration to ensure the reagent dose is appropriate and excess $\mathrm{Al}$ is not released into the environment. In order to achieve consistent results with this process, it is also key to properly maintain and clean the $\mathrm{pH}$ control system. When the process is performed successfully, sludge volume will account for approximately $30 \%$ of the water volume after settling, with a moisture content of $80 \%$ to $85 \%$. This sludge can be disposed of as a non-hazardous waste.

\section{Acknowledgements}

Funding for this study was provided by the Appalachian Research Initiative for Environmental Science (ARIES) at Virginia Tech. ARIES is an industrial affiliates program at Virginia Tech, supported by members that include companies in the energy sector. The research under ARIES is conducted by independent researchers in accordance with the policies on scientific integrity of their institutions. The views, opinions and recommendations expressed herein are solely those of the authors and do not imply any endorsement by ARIES employees, other ARIES-affiliated researchers or industrial members. Information about ARIES can be found at http://www.energy.vt.edu/ARIES. 


\section{$\underline{\text { Literature Cited }}$}

APEX Engineering. 2016. CESR Process for Sulfate Removal. Accessed on Jan 17, 2017 from http://www.apexengineering.us/CESR-Sulfate-Removal.html.

American Public Health Association (APHA). 2012. Standard Methods for the Examination of Water and Wastewater, 22 ${ }^{\text {nd }}$ Edition. American Public Health Association. Washington DC.

Clark, E.V., B.M. Greer, C.E. Zipper, and E.T. Hester. 2016. Specific conductance-stage relationships in Appalachian valley fill streams. Environmental Earth Sciences 75:1222. https://link.springer.com/article/10.1007\%2Fs12665-016-6026-2.

Fisher, R.A. 1950. Statistical methods for Research Workers. London: Oliver and Boyd.

Kemak, Zachary. 2016. Biological and Membrane Treatment Applications for the Reduction of Specific Conductivity and Total Dissolved Solids in Coal Mining Waters. Thesis submitted in partial fulfilment of the MS ENE degree. Virginia Tech. Blacksburg, Virginia.

Lorax Environmental. 2003. Treatment of Sulphate in Mine Effluents. International Network for Acid Prevention.

Pond, G.J., M.E. Passmore, N.D. Pointon, J.K. Felbinger, C.A. Walker, K.J. Krock, J.B. Fulton, and W.L. Nash. 2014. Long-term impacts on macroinvertebrates downstream of reclaimed mountaintop mining valley fills in central Appalachia. Environ Manag 54:919-933. https://doi.org/10.1007/s00267-014-0319-6.

Portland Cement Association (PCA). 2001. Concrete information: Ettringite Formation and the Performance of Concrete. Accessed on Jan 20, 2017 from http://www.cement.org/docs/default-source/fc_concrete_technology/is417-ettringiteformation-and-the-performance-of-concrete.pdf?sfvrsn=2.

Reinsel, M. 2015a. Sulfate Removal Technologies: A Review. Accessed on Jan 17, 2017 from http://www.wateronline.com/doc/sulfate-removal-technologies-a-review-0001.

Reinsel, M. personal communication, Nov. 20. 2015 b.

Rosseland, B.O., T.D. Eldhuset, and M. Staurnes. 1990. Environmental Effects of Aluminum. Environmental Geochemistry and Health, 12 (1-2): 17-27.

\section{https://doi.org/10.1007/BF01734045}


Sawalha, O. and M. Scholz. 2007. Assessment of Capillary Suction Time (CST) Test Methodologies. Environmental Technology, Vol. 28, Iss. 12. 2007. https://doi.org/10.1080/09593332808618898

Timpano, A.J., S.H. Schoenholtz, C.E. Zipper, and D.J Soucek. 2010. Isolating effects of total dissolved solids on aquatic life in central Appalachian coalfield streams. Proceedings, national meeting of the American Society of Mining and Reclamation, Pittsburgh, PA, pp 1284-1302. http://dx.doi.org/10.21000/JASMR10011284

United States Environmental Protection Agency (USEPA). 1988. Ambient Water Quality Criteria for Aluminum. Accessed on May 12, 2018 from https://nepis.epa.gov/Exe/ZyPDF.cgi/2000M5FC.PDF?Dockey=2000M5FC.PDF. Last accessed May 12, 2018.

United States Environmental Protection Agency (USEPA). 2011. A Field-Based Aquatic Life Benchmark for Conductivity in Central Appalachian Streams (Final Report). U.S. Environmental Protection Agency, Washington, DC, EPA/600/R-10/023F.

United States Environmental Protection Agency (USEPA). 2016. Ecological Toxicity Information. Accessed on Jan 17, 2017 from https://archive.epa.gov/reg5sfun/ecology/web/html/toxprofiles.html.

Vesilind, PA. 1988. Capillary Suction Time as a Measure of Sludge Dewaterability. Journal of the Water Pollution Control Federation, Vol. 60 (Feb, 1988). pp. 215-220. Water Environment Federation.

Water Online. 2016. A New Process for Sulfate Removal from Industrial Waters. Accessed on Jan 17, 2017 from http://www.wateronline.com/doc/a-new-process-for-sulfate-removalfrom-indust-0001. 